\title{
Pioneers in the cisterna magna puncture
}

\author{
Pioneiros na punção da cisterna magna \\ Thiago Ferreira Simões DE SOUZA
}

\begin{abstract}
At the beginning of the 20th century, cerebrospinal fluid (CSF) collection and analysis emerged as a promising aid in the diagnosis of diseases of the central nervous system. It was obtained through the established procedure of lumbar puncture, described by Heinrich Quinke in 1891. The search for an alternative way to gather the CSF arose in animal research, highlighting the cisterna magna as a promising source, with relative safety when performed by someone trained. Described initially and in detail by James Ayer in 1920, the procedure was widely adopted by neurologists and psychiatrists at the time, featuring its multiple advantages and clinical applications. After a period of great procedure use and exponential data collection, its complications and risks relegated the puncture of the cisterna magna as an alternative route that causes fear and fascination in modern neurology.
\end{abstract}

Keywords: cisterna magna; puncture; history of medicine; cerebrospinal fluid; suboccipital.

\section{RESUMO}

No início do século XX, a coleta e análise do líquido cefalorraquidiano (LCR) despontavam como um promissor auxílio no diagnóstico das doenças do sistema nervoso central. Sua obtenção se dava através do consagrado procedimento de punção lombar, descrito por Heinrich Quinke em 1891. A busca por uma via alternativa na obtenção do LCR ganhou relevância nas pesquisas animais, destacando-se na cisterna magna promissora fonte, com relativa segurança quando executada por alguém treinado. Descrito inicialmente e de maneira pormenorizada por James Ayer em 1920, o procedimento foi amplamente adotado por neurologistas e psiquiatras à época, com destaque para suas múltiplas vantagens e aplicações clínicas. Após um período de grande uso do procedimento e exponencial obtenção de dados, suas complicações e riscos relegaram a punção da cisterna magna como via alternativa que causa medo e fascínio na neurologia moderna.

Palavras-chave: cisterna magna; punção; história da medicina; líquor; suboccipital.

A standard diagnostic procedure in modern neurology, lumbar puncture was first formally described by Heinrich Quinke (1842-1922) in 1891, while researching a simple and safe way to drain the excess of cerebrospinal fluid (CSF) from a child with hydrocephalus. Quinke also counted the number of cells, measured the concentration of proteins, and identified the presence of bacteria in pathological situations in the CSF. The pathway for the analysis of CSF in clinical diagnosis had been opened ${ }^{1}$.

In the following years, there was an exponential understanding of the correlations between changes in CSF and central nervous system diseases ${ }^{2}$. New sites to obtain the precious liquid that was revolutionizing the neurological and psychiatric diagnosis became the object of interest of many researchers in the early twentieth century. In this context, the cisterna magna (CM), also known as Cerebellum-Medullary Cistern, stands out: dilation of the subarachnoid space between the inferior surface of the cerebellum, dorsal surface of the medulla oblongata, and dura mater in the atlanto-occipital region above the level of foramen magnum (Figure 1A). Westenhofer states that he had obtained CSF by puncture of the CM in 1905, although it was published only in $1924^{3}$. Obregia, in his work "La rachicenthesis sous-occipitale" from 1908, claims to have used the technique 22 times in that same year ${ }^{4}$. Even if performed by these or other researchers, the technique of this new type of puncture had not previously been described.

However, James Bourne Ayer (1882-1963) is considered the first to perform a suboccipital puncture in humans, with a detailed technical description. With interest in neuropathology after graduating from Harvard Medical School in 1907, he turned his attention to the new methods then arising from the study of CSF, even contributing to the investigation of outbreaks of meningococcal meningitis in the World War I. In 1919, after practicing the puncture of the CM in animal studies and subsequently

${ }^{1}$ Hospital da Cruz Vermelha Brasileira, Curitiba PR, Brazil.

Thiago Ferreira Simões DE SOUZA (iD) https://orcid.org/0000-0002-3695-5752

Correspondence: Thiago Ferreira Simões de Souza; Av.Vicente Machado, 1310; 80420-011 Curitiba PR, Brazil. E-mail:thiago.fsimoes@gmail.com

Conflict of interest: There is no conflict of interest to declare.

Received on May 10, 2019; Received in its final form on June 19, 2019; Accepted on July 10, 2019. 
in corpses, together with Paul Wegeforth and C.R. Essick, "The Method of Obtaining Cerebrospinal Fluid by Puncture of the Cisterna Magna (Cistern Puncture)" was published. In this paper, the authors work on a safe method to puncture the cistern in humans ${ }^{5}$.

In 1920, Ayer then published "Puncture of the Cisterna Magna", a detailed paper elaborating his developed puncture technique applied to 43 patients $^{6}$. He even mentions that until that moment, there were no reports in the literature on the suboccipital puncture as a procedure with clinical application, citing only its use in obtaining CSF in animals or the drainage of the CM by neurosurgeons. Ayer's technique consists briefly in positioning the patient in lateral decubitus, with slight cervical flexion, trying to maintain alignment of the cervical spine. With the left thumb, Ayer advocates the location of the spinal process of the first cervical vertebra, inserting the needle in a line drawn above the thumb. He further advises that the needle should be introduced with a slight cranial inclination, in an imaginary line between the external acoustic meatus and the glabella, until the perforation of the dura mater (Figure 1B).

In a particular passage of Ayer's paper, he argues that the unawareness of the patient regarding the proximity of the procedure from his medulla is the main advantage of the technique, preventing the patient from becoming apprehensive. Ayer adds that the practice of puncture of the CM without experience with corpses should be discouraged by the risks involved ${ }^{6}$.

In subsequent years after Ayer's description, there was euphoria in the use of the CM as an easy source of $\mathrm{CSF}^{7}$. Spiegel even features Germans replacing lumbar puncture to cistern puncture as a diagnostic test in the majority of neurologic clinics ${ }^{8}$. Part of this success in Germany is attributed to Karl Eskuchen (1885-1955), a pioneer in the knowledge about physiology and pathology of CSF, best known by his contributions on the lumbar puncture ${ }^{9}$. Eskuchen, independently from Ayer and his contemporaries, advocated the cisternal tap in his paper from 1923 "Die Punktion der Cisterna cerebellomedullaris" ${ }^{10-12}$.

The main applications of the CM puncture were in the diagnosis and treatment of syphilis and meningitis, in addition to the infusion of medications in the cisterna. The few reports of complications, perhaps underestimated, related to subarachnoid hemorrhages and direct puncture of spinal cord tissue. However, the first case of fatal complication was described in 1924: a 79-year-old patient who died of subarachnoid hemorrhage following perforation of posterolateral cerebellar artery with tortuosity by atherosclerosis ${ }^{13}$. In 1928, Spiegel states that there were in literature a number of up to ten thousand suboccipital punctures reported, with only two fatalities. He endorses the preferential use of the suboccipital route, highlighting the low incidence of complications and less pain compared to lumbar puncture. He also points out, as Ayer did, the need to practice the technique on cadavers to avoid complications ${ }^{8}$.

In 1929, Saunders and Riodan published a small report on 2,019 CM punctures performed on 539 patients, also emphasizing the safety of the procedure ${ }^{14}$. When reporting a death due to massive hemorrhage in the CM after perforation in the medulla, Vonderahe reinforces the need to follow Ayer's technical description and the practice in postmortem species $^{15}$. Kehrer, in 1949, reports that he performed 8,335 CM
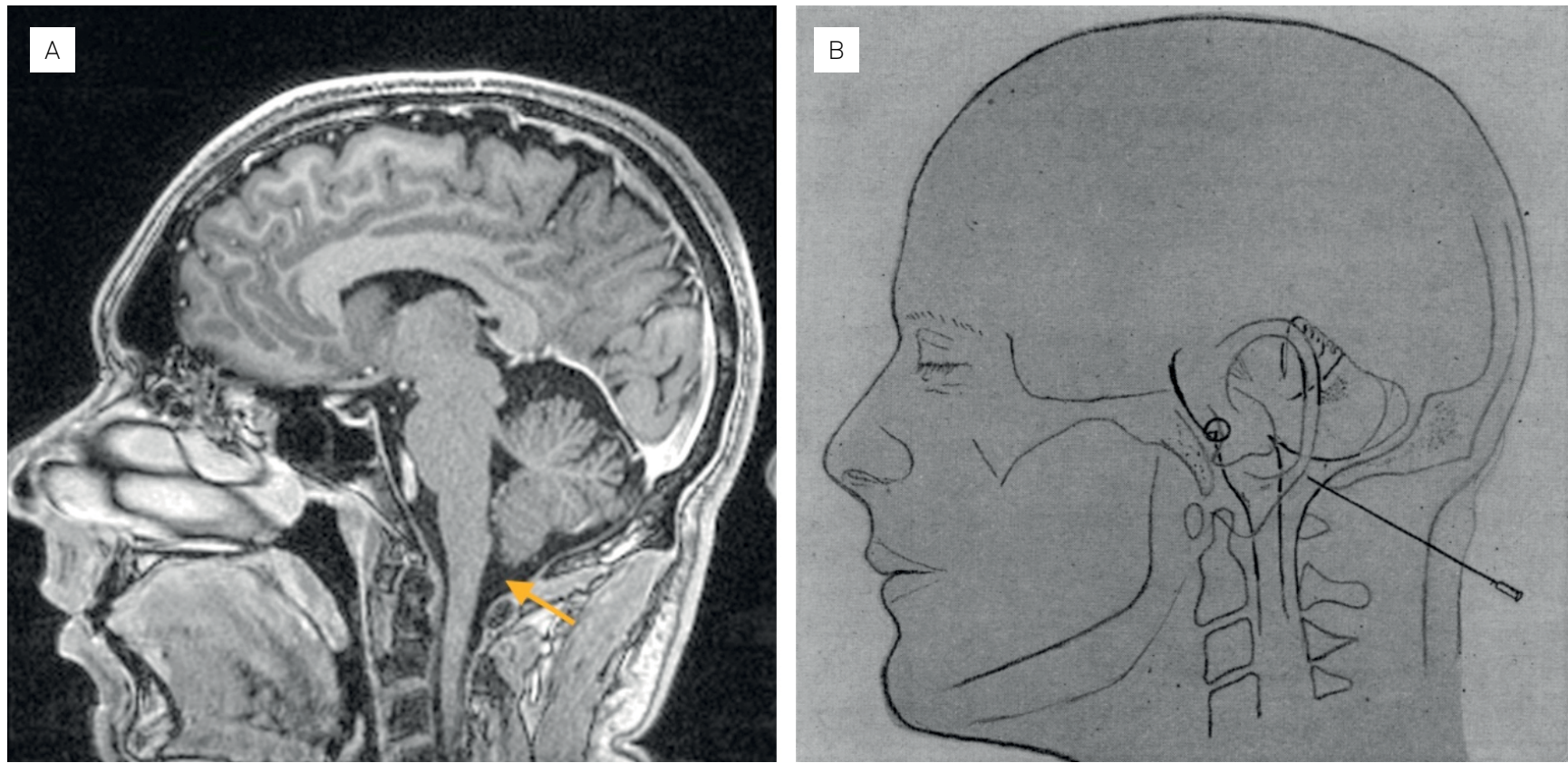

Figure 1. (A) Sagittal T1 weighted MRI showing the Cisterna Magna, also known as Cerebellum-Medullary Cistern (yellow arrow). (B) Image from Ayer's paper describing the correct needle positioning in his technique of cisterna magna puncture in a mid-sagittal plane 6 
punctures, with four deaths. The literature up to that time documented 28 deaths, the vast majority due to subarachnoid hemorrhage ${ }^{16}$.

In the early 1960s, Winn featured CM as the preferred site for the infusion of amphotericin B in the treatment of coccidioidal meningitis, arguing that intrathecal and intravenous therapy association were beneficial. In his 1964 article, he states that the intrathecal infusion of amphotericin $\mathrm{B}$ directly into the CM supports its fungistatic action, with less nephrotoxicity and possible reduction of the intravenous dose, with many side effects. Moreover, it is the procedure of choice for providing a more direct approach to the base of the encephalon, according to him, the preferred site of coccidioidal infection, eliminating the risk of arachnoiditis, common in lumbar infusions ${ }^{17}$. Such benefits were contested by Keane in 1973, reporting cases of severe complications in intrathecal amphotericin B infusion. In one of them, the patient received the medication through astonishing 39 suboccipital punctures straight, followed by headache and nausea, evolving with lethargy, dysarthria, and hemiparesis ${ }^{18}$.

In the following years, many other case series indicated a low rate of complications in the suboccipital approach. However, the fatal outcomes progressively led to the abandonment of the CM as a popular alternative to lumbar puncture. Once an abundant source of CSF collection and site to medication infusion, the CM route became a reason of fear and fascination in modern neurology, reserved as an uncomfortable substitute to lumbar puncture.

\section{References}

1. Quincke HI. Die Lumbarpunktion des Hydrocephalus. Berlin Klin Wschr. 1891;28:929-965.

2. Olukoga AO, Bolodeoku J, Donaldson D. Cerebrospinal fluid analysis in clinical diagnosis. J Clin Pathol. 1997 Mar;50(3):187-92. https://doi. org/10.1136/jcp.50.3.187

3. Westenhofer M.Zur Geschichte der Okzipitalinzision und Punktion. Munchen med Wchnschr. 1924;71:687.

4. Obregia A. La rachicenthesis sous-occipitale. Compt Rend Soc Biol. 1908;65:277.

5. Denny-Brown D, Viets H, Adams R, Schwab R, Kubik C, Smith R. James Bourne Ayer, MD 1882-1963. Arch Neurol. 1964 Oct;11(4):44951. https://doi.org/10.1001/archneur.1964.00460220111015

6. Ayer JB. Puncture of the Cisterna Magna. Arch NeurPsych.1920 Nov;4(5):529-41. https://doi.org/10.1001/ archneurpsyc.1920.02180230052005

7. Ayer JB. Puncture of the Cisterna Magna, Report of One Thousand, Nine Hundred and Eighty-Five Punctures. JAMA. 1923 Aug;81(5):358-60. https://doi.org/10.1001/jama.1923.02650050012004

8. Spiegel L. The Technic of Cistern Puncture (Cisterna Magna). Arch Derm Syphilol. 1928 Sep;18(3):420-2. https://doi.org/10.1001/ archderm.1928.02380150086011

9. Eskuchen K. Die Lumbalpunktion. München-Schwabing. Berlin and Viena: Urban and Schwarzenberg; 1919.
10. Eskuchen, K. Die Punktion der Cisterna Cerebello-medullaris (Technik experimentelle und klinische Verwendung). Klin Wchnschr. 1923 Oct;2(40):1830-3. https://doi.org/10.1007/BF01716646

11. Loebe FM. Karl Eskuchen: A nearly forgotten pioneer in cerebrospinal fluid research. Psychiatr Neurol Med Psychol (Leipz). 1983 Sep;35(9):561-5.

12. Loebe FM. History and significance of suboccipital puncture. Psychiatr Neurol Med Psychol (Leipz). 1988 Oct;40(10):617-20.

13. Nonne MG. Meine Erfahrungen uber den Subokzipitalstich auf der Basis von 310 Fallen. Med Kln. 1924;20:919-922.

14. Saunders HC, Riordan TJ. Cisternal or Suboccipital Puncture. N Engl J Med. 1929 Jul;201(4):66-168. https://doi.org/10.1056/ nejm192907252010406

15. Vonderahe AR, Haberman FC. Injury of Medulla in Puncture of Cisterna Magna. Arch NeurPsych. 1933 Jan;29(1):166-7. https://doi. org/10.1001/archneurpsyc.1933.02240070172013

16. Kehrer HE. Uber Zwischenfiille bei der Suboccipitalpunktion. Deutsche Ztschr Nervenh. 1949;161:98-110.

17. Winn WA. The Treatment of Coccidioidal Meningitis - The use of Amphotericin B in a Group of 25 Patients. Calif Med. 1964 Aug;101(2):78-89.

18. Keane JR. Cisternal puncture complications - Treatment of coccidioidal meningitis with amphotericin B. Calif Med. 1973 Sep;119(3):10-5 